\title{
Kaplice św. św. Piotra i Pawła oraz św. Mikołaja $w$ przestrzeni katedry krakowskiej w XIII-XV wieku
}

Streszczenie. Artykuł prezentuje propozycję nowego odczytania funkcji, historii i przekształceń formalnych kaplic św. św. Piotra i Pawła oraz św. Mikołaja, przylegających do korpusu nawowego katedry w Krakowie. Kaplice te dostawiono jako aneksy do katedry romańskiej, ale podczas powstawania obecnego kościoła (1320-1364) zostały przebudowane i włączone do nowej budowli. Kaplica św. św. Piotra i Pawła została prawdopodobnie ufundowana przez biskupa Prandotę jako miejsce spoczynku relikwii św. Stanisława po jego kanonizacji w 1253 roku. W gotyckiej katedrze ołtarz tego świętego przeniesiono do jej centralnego punktu, ale obie kaplice także odgrywały rolę w jego kulcie. W kaplicy św. Mikołaja wystawiano bowiem relikwie głowy męczennika, zaś w kaplicy św. św. Piotra i Pawła - relikwie ramienia oraz dawny kamienny sarkofag, w którym szczątki spoczywały w okresie po kanonizacji.

Słowa kluczowe: kult świętych, relikwie, architektura gotycka, Kraków, średniowiecze

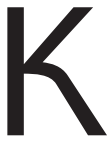

aplice św. św. Piotra i Pawła oraz św. Mikołaja, przylegające od południa i północny do wschodniego przęsła korpusu nawowego katedry w Krakowie (il. 1-2), uchodzą za najstarsze w wieńcu kaplic otaczających kościół. Ich dzieje mają bowiem sięgać w głąb wieku XIII, a więc do okresu poprzedzającego powstanie obecnie istniejącej katedry. Ponadto przynajmniej od XV wieku obie kaplice odgrywały ważną rolę w liturgii poświęconej współpatronowi katedry, biskupowi i męczennikowi - Stanisławowi ze Szczepanowa. Z galerii umieszczonej ponad wejściem do kaplicy św. Mikołaja w dni świąteczne prezentowano wiernym relikwiarz głowy świętego, zaś w kaplicy św. św. Piotra i Pawła czczono relikwiarz ramienia oraz pusty sarkofag, w którym niegdyś spoczywały święte szczątki. Dość powszechny jest też pogląd, po raz pierwszy wyrażony przez Tadeusza Wojciechowskiego, wedle którego podczas budowy gotyckiej katedry obie kaplice zostały 


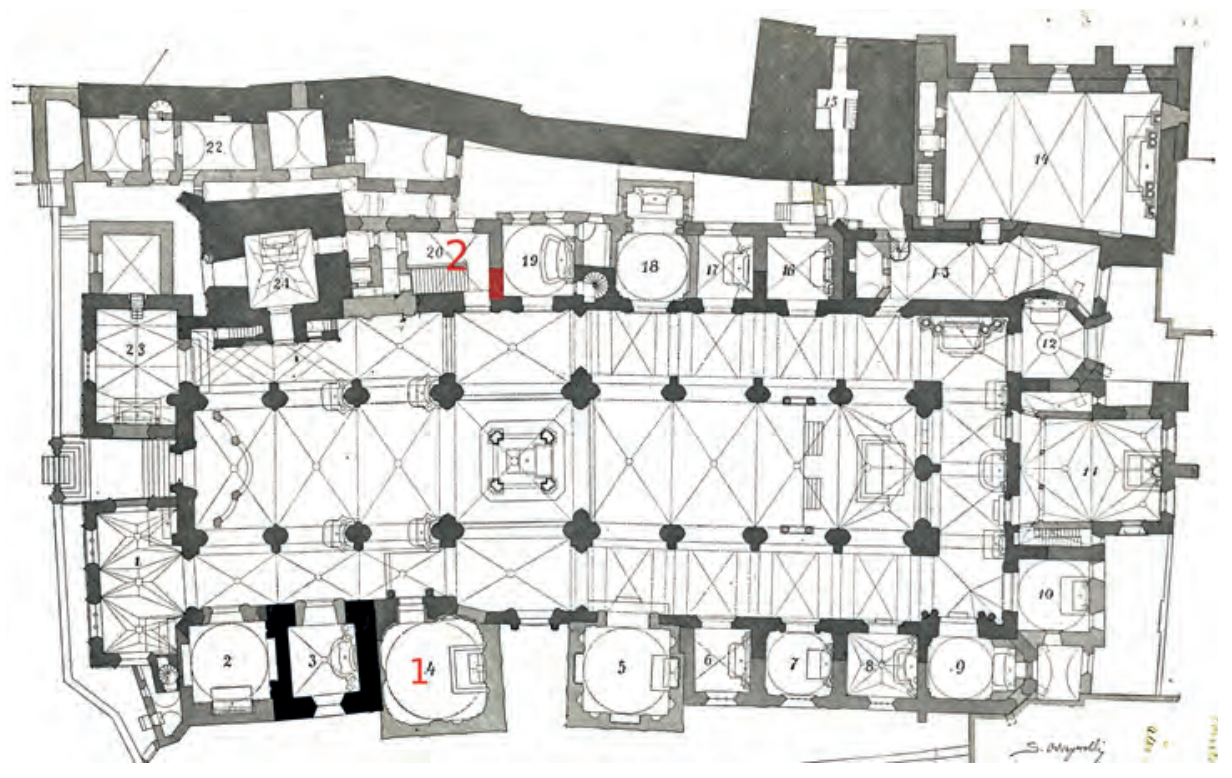

1. Kraków, katedra, rzut według Sławomira Odrzywolskiego, czerwonym prostokątem oznaczono relikt przypory w ścianie między kaplicami św. Mikołaja i św. Tomasza; 1. - kaplica św. św. Piotra i Pawła; 2. - dawna kaplica św. Mikołaja, za: WoJCIECHOWSKı 1900, s. 12

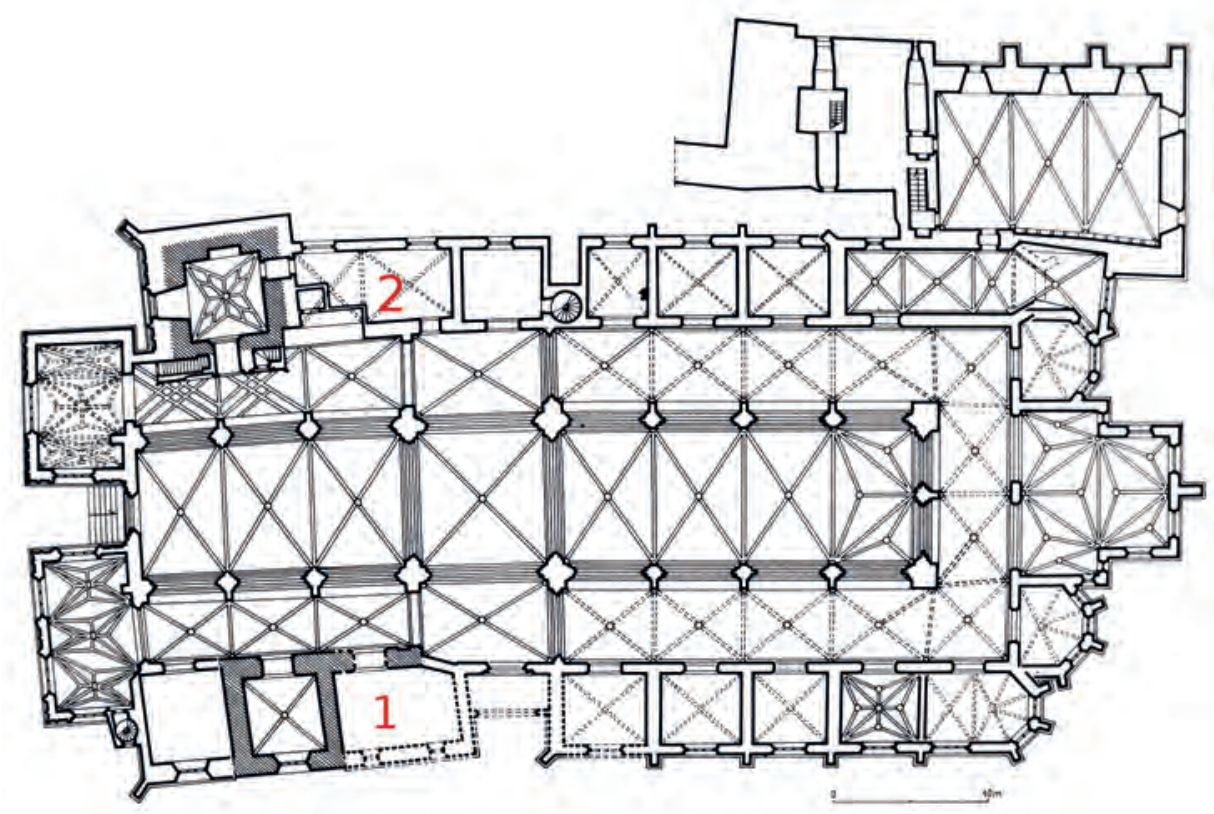

2. Kraków, katedra, rekonstrukcja rzutu w późnym średniowieczu; 1. - kaplica św. św. Piotra i Pawła; 2. - kaplica św. Mikołaja, za: Architektura 1995, t. 2, s. 431 
zachowane $\mathrm{w}$ ich romańskiej formie i włączone w obręb nowego kościoła jako - używając określenia samego Wojciechowskiego - remanenty ${ }^{1}$, spolia lub też - odwołując się do nowszych propozycji badaczy niemieckich - nośniki pamięci (Stephan Albrecht) czy materialne ślady przeszłości (Hauke Horn) $)^{2}$.

Możliwości czy to weryfikacji, czy uszczegółowienia zarysowanej wyżej narracji są jednak poważnie ograniczone. Żadna z omawianych $\mathrm{w}$ niniejszym referacie kaplic nie istnieje w swojej średniowiecznej formie. Nadziemna część kaplicy św. św. Piotra i Pawła została całkowicie zburzona pod mauzoleum Wazów; pewne partie murów przetrwały pod powierzchnią gruntu, i tam jednak nie obyło się bez przekształceń związanych z nieco wcześniejszym urządzeniem krypty (il. 3) ${ }^{3}$. Kaplica św. Mikołaja uniknęła co prawda aż tak radykalnych przemian, jednak liczne przebudowy, a wreszcie przekształcenie jej w XVIII wieku poprzez wybudowanie schodów do nowego kapitularza uczyniło średniowieczną formę niemal zupełnie nieczytelną (il. 4).

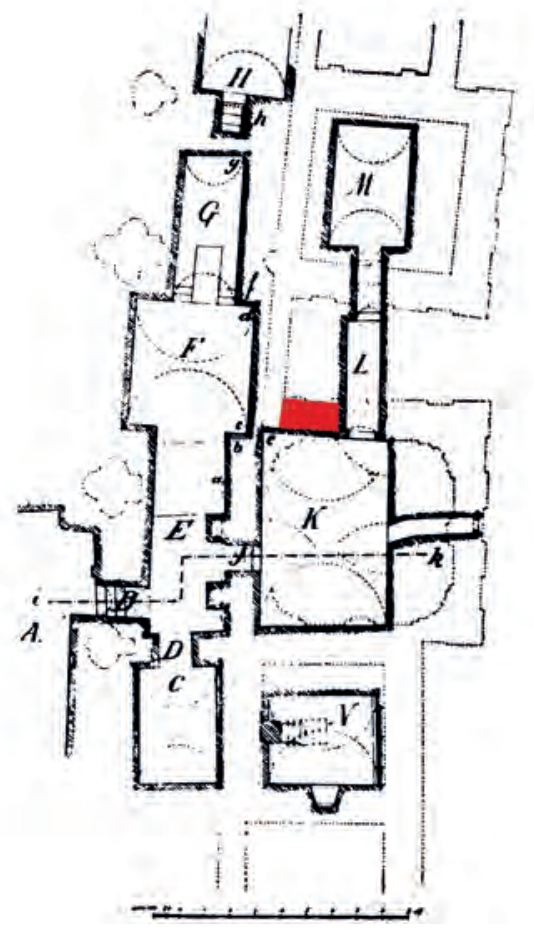

3. Kraków, katedra, rzut krypt pod częścią południową według Sławomira Odrzywolskiego z poprawkami Tadeusza Wojciechowskiego; K - krypta Wazów; kolorem czerwonym zaznaczono fundament przypory w ścianie wschodniej, za: WoJCIECHOWSKI 1900, s. 143

\footnotetext{
Wojciechowski 1900, passim. Badacz za remanent romański uważał także kaplicę św. Mateusza (Lipskich); w okresie tym nie znano jednak żadnych pozostałości średniowiecznej kaplicy rozebranej w XVII wieku, a podstawowym argumentem był dla Wojciechowskiego akt uposażenia kaplicy wystawiony przez biskupa Bodzantę, w którym ołtarz w kaplicy określono jako dudum aedificatum (KDKK, nr 204). Słowo „dudum” zdaniem Wojciechowskiego należy tu rozumieć jako „dawno”, podobnie jak w przypadku dokumentu uposażenia ołtarza św. św. Piotra i Pawła (WoJCIECHOWSKI 1900, s. 76-78). Wydaje się jednak, że w obu tych przypadkach termin ten należy raczej tłumaczyć jako „już (skończony)”. W późniejszej literaturze do tezy tej odniósł się bodaj tylko Paul Crossley, który jednak uznał, że nawet jeśli gdzieś w katedrze romańskiej znajdował się ołtarz św. Mateusza, to kaplica przy obejściu powstała najwcześniej w okresie budowy gotyckiego chóru (Crossley 1985, s. 28-29).
}

\footnotetext{
2 Albrecht 2003, passim; Horn 2017, s. 19-80.

3 Zob. RoŻeK 1980, s. 141; CZYŻEWSKI 2016, s. 83-84.
} 


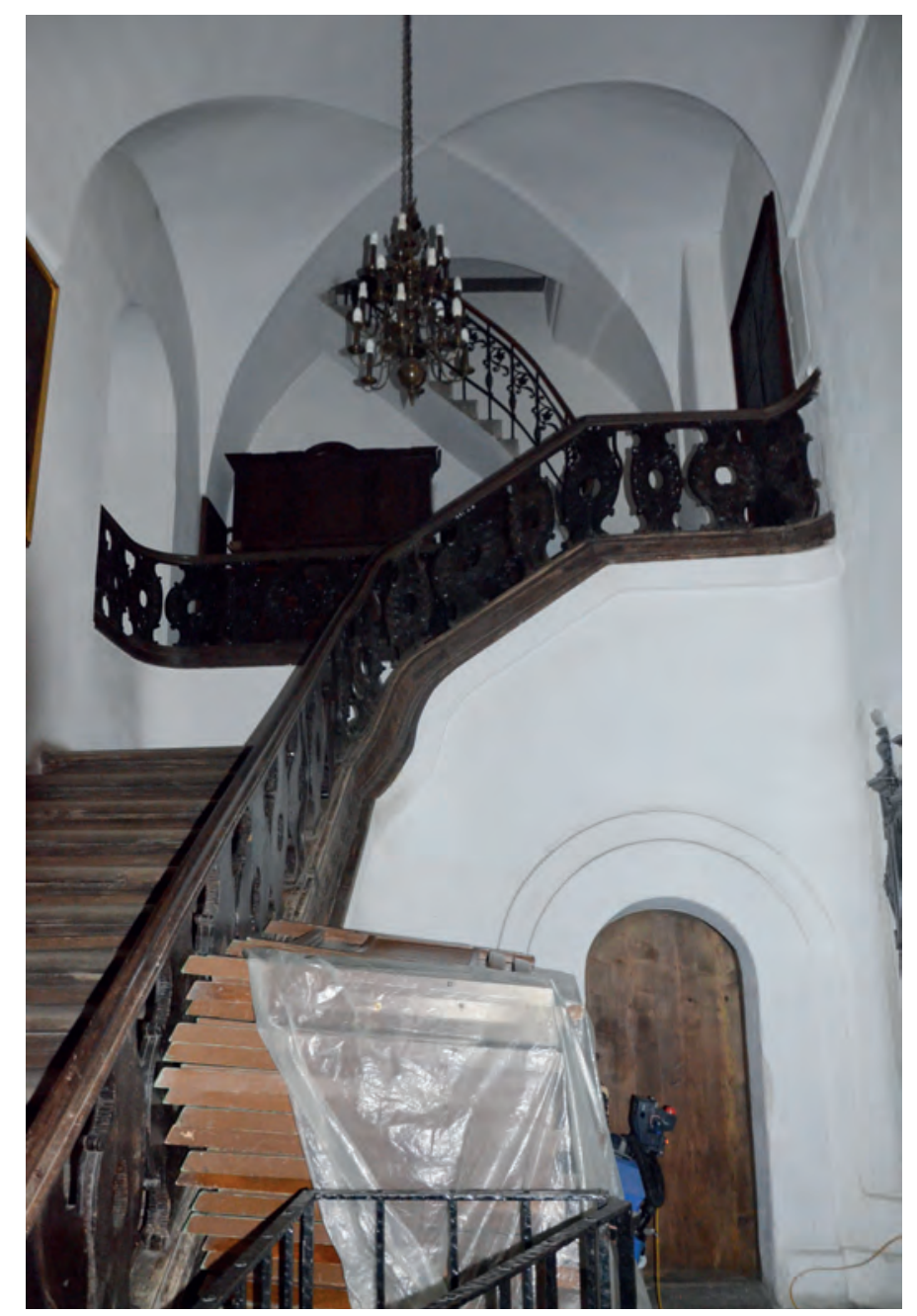

4. Kraków, katedra, wnętrze dawnej kaplicy św. Mikołaja ku zachodowi, fot. autor

Brak też, niestety, źródeł pisanych pochodzących z XIII wieku, które bezpośrednio odnosiłby się do omawianych kaplic, a przynajmniej jednoznacznie potwierdzały ich istnienie. Kodyfikatorem ich długiej historii, przynajmniej w odniesieniu do kaplicy św. św. Piotra i Pawła, był dopiero Jan Długosz.

Obie kaplice w większej części przylegają do ścian magistralnych wschodnich przęseł naw bocznych. Od zachodu ograniczają je wieże katedry; w przypadku kaplicy św. św. Piotra i Pawła jest to wieża Wikaryjska, której dolna część stanowi relikt tzw. katedry Hermanowskiej (il. 2). Północna ściana kaplicy, przynajmniej w partii podziemnej, również stanowi pozostałość muru magistralnego poprzedniego kościoła i przebiega nierównolegle do linii gotyckich filarów międzynawowych. Kaplica 


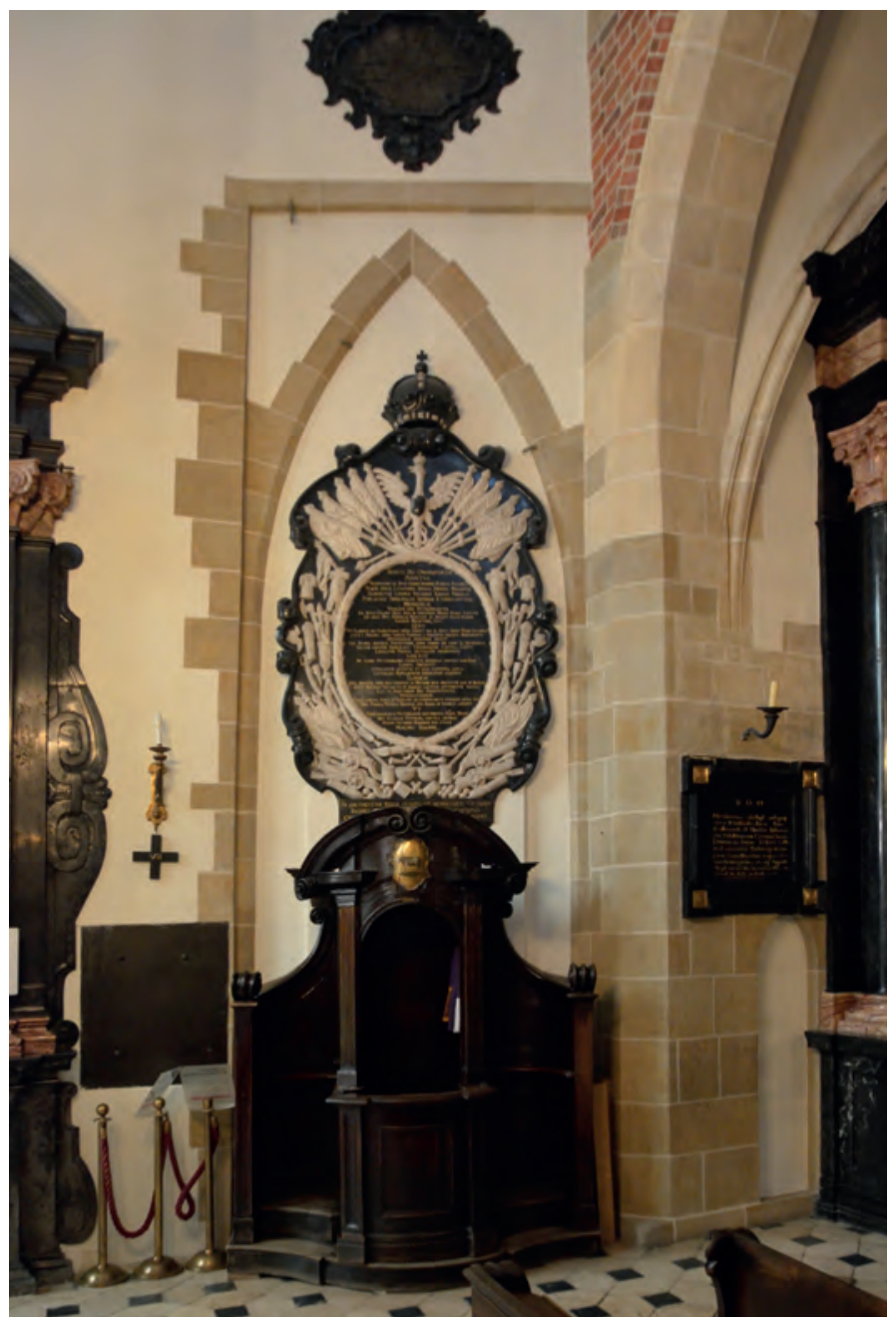

5. Kraków, katedra, dawne wejście z transeptu do kaplicy św. św. Piotra i Pawła, fot. autor

św. Mikołaja, jak się wydaje, także przylegała pierwotnie do wieży romańskiej, która jednak na początku XV stulecia została zastąpiona znacznie masywniejszą strukturą, częściowo wprowadzoną zarówno do wnętrza kaplicy, jak i nawy północnej. Szczególnie charakterystyczny jest sposób rozplanowana wschodnich części obu kaplic, które nie kończą się równolegle z nawami bocznymi, lecz zachodzą na szczytowe ściany transeptu. W przypadku kaplicy św. św. Piotra i Pawła zaadaptowanie fragmentu muru korpusu katedry romańskiej zaowocowało silnym zniekształceniem zarówno nawy południowej, jak i południowego ramienia transeptu, którego

4 Wojciechowski 1900, s. 114-120; WALCZAK 1992, s. 7-14. 
południowo-zachodni narożnik został ścięty. Wydaje się, że w XIV wieku kaplice były skomunikowane zarówno z nawami bocznymi, jak i transeptem ${ }^{5}$ (il. 2, 5), choć w obu przypadkach stan ten uległ przekształceniu.

W obu aneksach można jednak znaleźć szereg dowodów wskazujących na to, że o takiej aranżacji przestrzeni centralnej części katedry zdecydowano dopiero podczas budowy korpusu; nowych przesłanek na poparcie tej rezy dostarczyły niedawno badania przeprowadzone w obrębie krytpy południowej m.in. przez Janusza Firleta, Paława Kajfasza i Ignacego Jakubczyka ${ }^{6}$. Pierwotny projekt, realizowany od roku 1320, raczej nie uwzględniał połączenia kaplic z transeptem; co więcej, wydaje się też prawdopodobne, że planowano wówczas całkowite wyburzenie zachodniej części romańskiego korpusu, nie wyłączając kaplic. We wschodnich ścianach obu budowli widoczne są dolne partie przypór prostopadłych do ścian magistralnych naw bocznych, wykonanych z rozbiórkowej kostki wapiennej - materiału charakterystycznego dla najstarszych partii gotyckiego chóru; w kaplicy św. Mikołaja przypora tkwi w ścianie oddzielającej ją od sąsiedniej kaplicy św. Tomasza Apostoła7 (il. 1, 6). Po stronie południowej fundament jej odpowiednika odkryto niedawno po usunięciu tynku ze wschodniej ściany krypty Wazów ${ }^{8}$ (il. 3). Druga z przypór położona jest nie tylko (przynajmniej w przybliżeniu) równolegle do północnej, lecz także przy zachodnim krańcu regularnego odcinka południowej ściany transeptu, tuż przed jej załamaniem. Układ przypór wskazuje, że pierwotnie planowany transept, podobnie jak ostatecznie zrealizowany, nie miał wykraczać poza linię murów obejścia i naw bocznych, jednak jego szerokość byłaby wyraźnie mniejsza; w efekcie w ogóle nie byłby on widoczny w rzucie, a jedynie w bryle budowli. Jakkolwiek jest to rozwiązanie dość osobliwe, to jednak można wskazać takie realizacje na obszarze Alzacji, z której prawdopodobnie wywodził się architekt chóru katedry - młodszy kościół św. Piotra w Strasburgu oraz kościół Atonitów w Pont-à-Mousson (il. 7). Podobnej formy pierwotnie planowanego transeptu już w latach 70. XX wieku domyślał się

\footnotetext{
W kaplicy św. Mikołaja częściowo zachowała się zamurowana arkada, która mimo licznych przekształceń w drugiej połowie XVIII wieku łączyła ją z nawą północną, oraz obecnie nowożytny portal do transeptu. W przypadku kaplicy św. św. Piotra i Pawła odwrotnie - mimo zamurowania przetrwało obramienie przejścia z transeptu do dawnej kaplicy, jednak obecną kaplicę Wazów z nawą południową komunikuje okazały portal z XVII wieku, który jednak być może powstał w miejscu dawniejszego otworu (WĘCŁAWOWICZ 2014, s. 74 i przyp. 81). Badacz wskazywał na stosunkowo niewielką wysokość przelotu siedemnastowiecznego portalu, jakkolwiek nigdy nie przeprowadzono w jego sąsiedztwie inwazyjnych badań architektonicznych, które mogłyby zweryfikować tę tezę.

6 Firlet 2016.

Jako pierwszy opisał ją: WOJCIECHOWSKi 1900, s. 83-84.

8 Przyporę odkryto podczas prac konserwatorskich prowadzonych w latach 2017-2018 pod kierunkiem Ignacego Jakubczyka.

9 BRACHMANN 2008, s. 26-30.
} 
$45 \mid \begin{gathered}\text { TECHNE } \\ \text { TE X N H } \\ \text { SERIA NOWA }\end{gathered}$

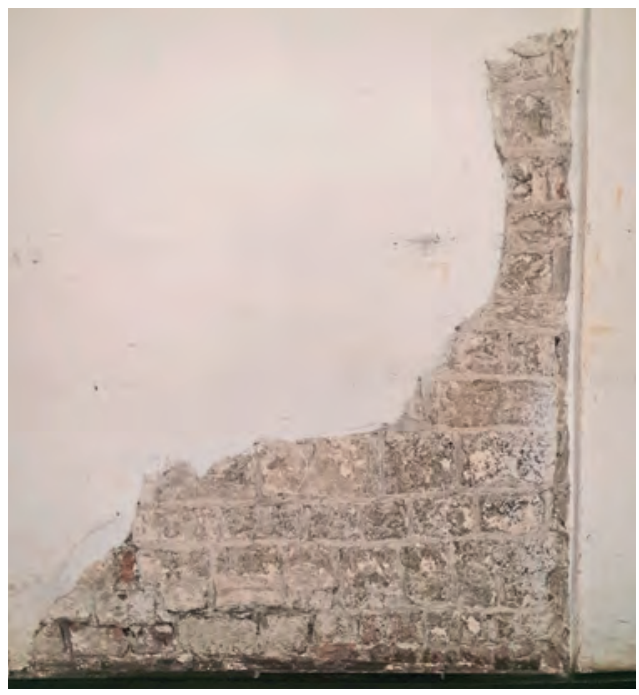

6. Kraków, katedra, relikt kamiennej przypory we wschodniej ścianie dawnej kaplicy św. Mikołaja, fot. Jakub Adamski

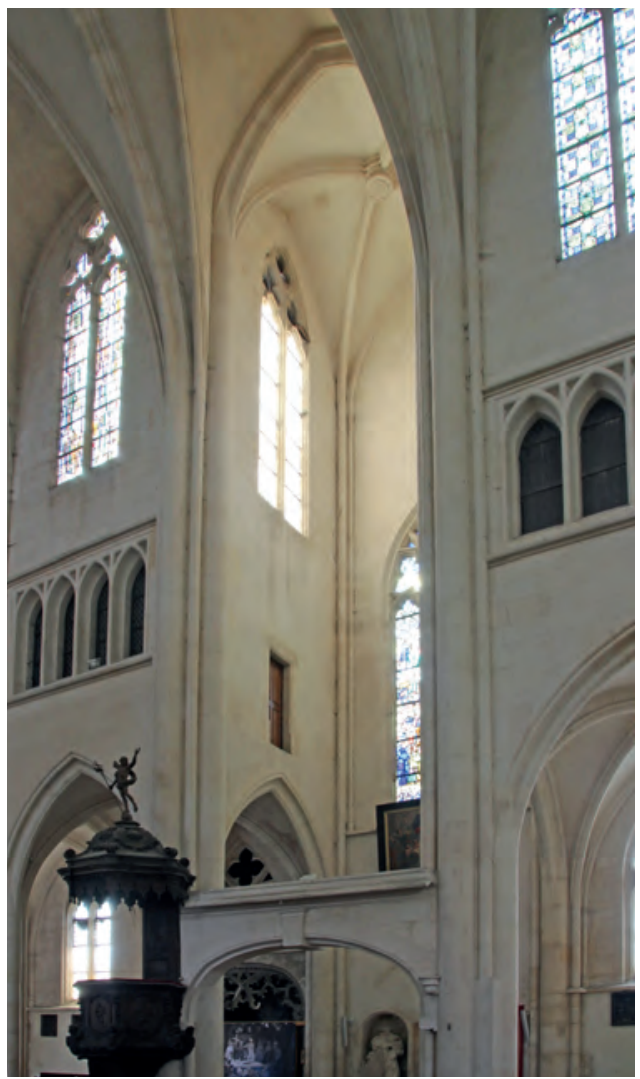

7. Pont-a-Mousson, kościół Antonitów, widok na południowe ramię transeptu, fot. Jakub Adamski 
skądinąd Jerzy Pietrusiński ${ }^{10}$. Do zmiany projektu doszło, jak się zdaje, przed połową lat 40. XIV stulecia. Do tego czasu wzniesiono zapewne dolną część północnej ściany transeptu oraz prawie całą ścianę południową, w której wykonano okno położone $\mathrm{w}$ osi pierwotnie planowanej ściany. Poszerzenie transeptu wiązało się z podjęciem decyzji o skomunikowaniu z nim kaplic oraz wykorzystaniu znacznych partii romańskiego korpusu - fragmentów murów obwodowych, krypty, wież, a także przynajmniej kaplicy św. św. Piotra i Pawła. Zaowocowało to nie tylko wspomnianym już nieregularnym rozplanowaniem południowej części całego założenia, ale też problemami technicznymi. Ukośny odcinek ściany południowej transeptu został przerzucony ponad narożnikiem tworzonym przez mur nawy południowej i wymurowaną już przyporę, w tej fazie przedłużoną; w związku z tym pozbawiony jest fundamentu i wspiera się na ukrytej pod posadzką arkadzie odsłoniętej w kaplicy Wazów ${ }^{11}$. Same kaplice natomiast przedłużono ku wschodowi. W zachodniej części południowej ściany krypty Wazów widoczny jest odcinek muru wybudowany z wtórnie użytego kamienia, który można identyfikować jako pozostałość pierwotnej kaplicy dostawionej do romańskiej katedry. Włączenie owej kaplicy w obręb nowego kościoła musiało więc wiązać się z daleko posuniętą przebudową ${ }^{12}$. Obejmowała ona rozbiórkę ściany wschodniej i przedłużenie, a najpewniej też rozbiórkę sklepienia (o ile istniało w pierwotnej kaplicy) i nadbudowę - czternastowieczna posadzka znalazła się bowiem nieco ponad 2 metry ponad poziomem użytkowym z poprzedniego stulecia. Przebudowana kaplica zawierałą więc w sobie pewne partie dawniejszej budowli, lecz nie sposób orzec, czy i w jaki sposób były one wyeksponowane. Wszystkie te prace musiały się zakończyć przed 3 maja roku 1349, kiedy to biskup Bodzanta ustanowił w kaplicy altarię, uposażając ją hojnie na prośbę kantora Piotra, który przekazał na budowę katedry 100 grzywien; w dokumencie tym kaplica została określona jako dudum edificata et consecrata ${ }^{13}$. Wspomniany dokument określa też położenie kaplicy iuxta tumbam st. Stanislai, do czego jeszcze trzeba będzie wrócić, a zarazem stanowi najstarsze źródło, które odnosi się do jej funkcjonowania. Także prace nad sąsiednim korpusem kościoła musiały być już dość zaawansowane, skoro dwa miesiące wcześniej ufundowano ołtarz św. Marcina w nawie głównej.

\footnotetext{
10 Pietrusiński 1975, s. 257-258.

11 Wojciechowski 1900, s. 148; Pietrusiński 1975, s. 265; Firlet 2016, s. 163-170.

12 Fragment opisanego wątku był znany już Wojciechowskiemu (WOJCIECHOWSKI 1900, s. 147); zob. także FIRLET 2016, s. 167. Jednak dopiero w roku 2018 całkowicie usunięto tynk ze ścian kaplicy, odsłaniając pełny kontekst, w tym wspomnianą dylatację. Nie jest to jednak, jak uważano wcześniej, mur z kamienia łamanego, wykonano go bowiem z przemieszanego materiału rozbiórkowego z dużym udziałem „romańskiej” kostki.

13 KDKK, 1, s. 238.
} 
Jednoznaczne określenie dokładnej metryki pierwotnej kaplicy św. św. Piotra i Pawła jest na obecnym etapie badań zadaniem niewykonalnym. Powszechne przekonanie, że jej fundatorem był biskup Prandota, nie ma jednoznacznych podstaw źródłowych, lecz wynika z relacji o odnalezieniu w niej w roku 1454 grobu biskupa $^{14}$. Ponadto $\mathrm{w}$ czasach nowożytnych przedwazowską kaplicę nazywano Prandocińską ${ }^{15}$. Przyjęcie tej tezy pozwala usytuować budowę kaplicy w latach episkopatu Prandoty, to jest 1242-1266. Jak jednak zobaczymy dalej, za najbardziej prawdopodobny czas jej powstania można uznać okres około roku 1254. Przede wszystkim zaś nie ma podstaw, by negować tradycję o odnalezieniu 200 lat później właśnie w tym miejscu grobu Prandoty, bez różnicy, czy doszło do niego, jak zapisano $\mathrm{w}$ rejestrze cudów dokonanych za sprawą biskupa, przypadkiem, czy też, jak sugerowała Maria Starnawska, w efekcie akcji poszukiwawczej świadomie zaplanowanej przez Zbigniewa Oleśnickiego ${ }^{16}$. Brak też jednak, jak podkreślał Firlet, przesłanek do rekonstruowania w tym miejscu jakiejkolwiek budowli w okresie przed połową XIII wieku.

Nie lepiej sytuacja przedstawia się w przypadku kaplicy św. Mikołaja. Jej najwcześniejszych dziejów nie naświetlają ani bezpośrednio się do niej odnoszące źródła z epoki, ani też późniejsza tradycja. Jednakże altaria pod tym wezwaniem powstała przed rokiem 1327, kiedy została wymieniona w sporządzonym przez kolektorów - Andrzeja de Vernulis i Piotra de Alvernia -rejestrze świętopietrza ${ }^{17}$. Za argumenty przemawiające za jej trzynastowieczną metryką Wojciechowski uważał także nieregularny plan, w tym zwłaszcza fakt, że wschodnia część kaplicy zachodzi częściowo na północną ścianę transeptu, a usytuowanie arkady łączącej ją dawniej z nawą północną nie ma związku z podziałami gotyckiego korpusu; o takiej metryce miał też świadczyć wątek ceglanego muru w jej zewnętrznej elewacji, w sąsiedztwie przejścia prowadzącego na dziedzińczyk przed murem obronnym Wawelu ${ }^{18}$. Wschodnia ściana kaplicy powstała jednak, tak jak w jej południowej odpowiedniczce, poprzez przedłużenie narożnej przypory wąskiego transeptu. Pierwotna kaplica była więc krótsza albo jej wschodnią część całkowicie rozebrano przy realizacji pierwszego projektu transeptu. Ponadto wspomniany fragment ceglanej ściany

\footnotetext{
14 MPH, 4, s. 443-444; DŁugosz [1887], s. 403; Wojciechowski 1900, s. 150 (przy czym zdaniem badacza Prandota w istocie przebudował na kaplicę pozostałość najstarszej katedry z XI wieku); JANICKI 2003, s. 52; FIRLET 2016, s. 167; ogólnie o fundacji kaplicy przed połową XIII wieku: Pietrusiński 1975, ryc. 1 (bez uzasadnienia); Kumor 1998, s. 304-305; PiAnOwSKi 2007, s. 13.

15 WOJCIECHOWSKi 1900, s. 149.

16 StARnAWSKa 2008, s. 262-264.

17 MPV, 1, s. 112.

18 WojCIECHOWSKi 1900, s. 126-127.
} 
TECHN E

T E X N H

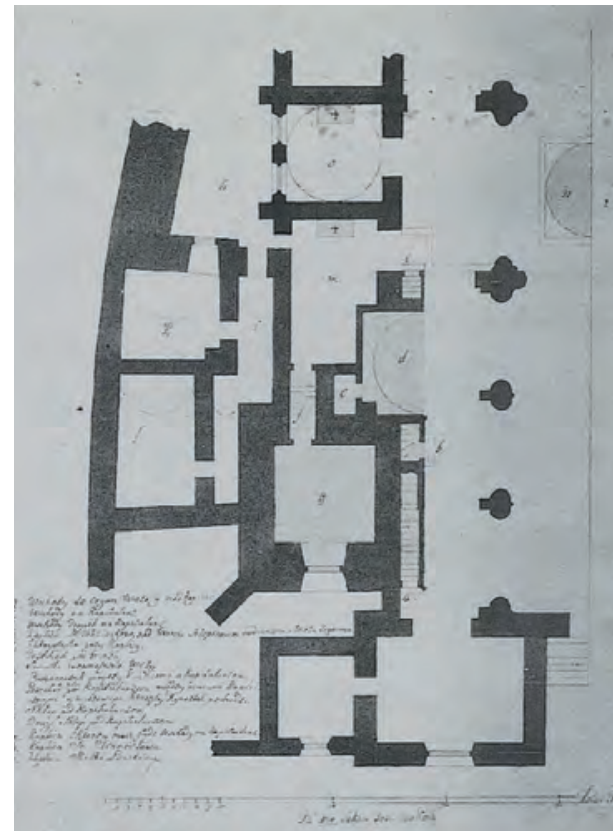

8. Kraków, katedra, rzut północnej części korpusu nawowego z kaplicami św. Mikołaja i Niewiniątek (Hińczy z Rogowa) w centrum, według Dominika Pucka, 1773, za: WALCZAK 1992, s. 18

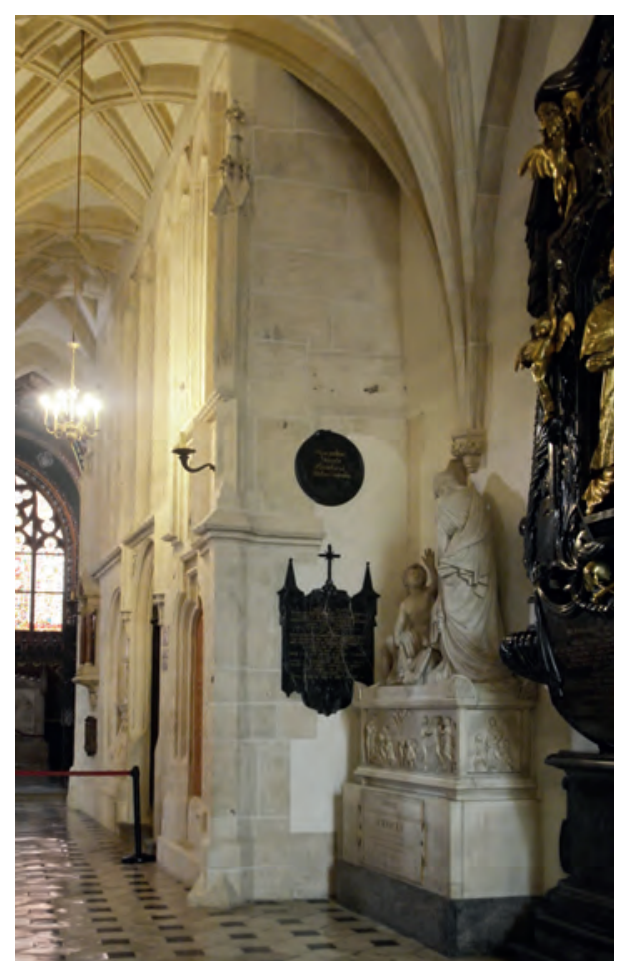

9. Kraków, katedra, nawa północna ku zachodowi, widoczny narożnik wieży wraz z reliktem galerii ponad wejściem do kaplicy św. Mikołaja, fot. autor 
wydaje się zdradzać raczej predylekcję do układu gotyckiego. Firlet i Pianowski na sporządzonym przez siebie planie stratygraficznym katedry datowali całą północną ścianę kaplicy na XIV wiek ${ }^{19}$. Taka interpretacja znajduje uzasadnienie w orientacji ściany, która nie jest równoległa do południowego boku kaplicy pokrywającego się z przebiegiem muru romańskiego korpusu, co nadaje obiektowi lekko trapezoidalny kształt. Ponadto przebieg ściany stanowi niemal (lecz nie dokładnie) przedłużenie północnego boku kaplic przy chórze. Datowanie Firleta i Pianowskiego zapewne oparte jest także o dokumentację z badań wykopaliskowych, które w roku 1967 Józef Niżnik przeprowadził we wschodniej części kaplicy. Odsłonięto wówczas mury fundamentowe ściany wschodniej (z fundamentem przypory i dowiązanym przedłużeniem ku północy) oraz wschodniego odcinka ściany północnej pod wyjściem na dziedzińczyk. Wszystkie mury wykonane są głównie z łamanego kamienia zalanego zaprawą. Na rysunku dokumentującym ostatni z wymienionych punktów widoczne jest jednak przejście od luźno ułożonego, nieregularnego materiału przy wschodnim narożniku do staranniejszego wątku z udziałem kostki na zachodzie ${ }^{20}$. Charakterystyczne jest także usytuowanie i kształt arkady, która komunikowała ją z nawą północną. Arkada została kilkukrotnie przekształcona; jej przemiany drobiazgowo przeanalizowali Wojciechowski, a później Walczak. Przed rokiem 1437 z inicjatywy Zbigniewa Oleśnickiego ujęto ją w dwie niewielkie klatki schodowe oraz poprowadzoną ponad otworem galeryjkę (il. 8-9). Ćwierć wieku później arkada została poszerzona w głąb kaplicy św. Mikołaja, a uzyskaną w ten sposób przestrzeń zaadaptowano na nową kaplicę fundacji Hińczy z Rogowa ${ }^{21}$. Tak powstała aranżacja przetrwała w ogólnym zrębie do lat 70. XVIII wieku, kiedy to galerię zniesiono, arkadę zamurowano, a wewnątrz kaplicy umieszczono schody do kapitularza. Plan „drezdeński” sprzed koronacji Augusta III oraz pomiar wykonany przez architekta Dominika Pucka bezpośrednio przed przebudową pozwalają jednak stwierdzić, że arkada była usytuowana bez widocznego związku z rytmem przęseł gotyckiego korpusu $^{22}$. Co więcej, kształt nowej wieży północnej został w części dostosowany

\footnotetext{
19 Firlet/Pianowski 2000, plan II; zaktualizowana wersja w: Firlet/Pianowski 2017, s. 49.

20 AZK, PZS A Rej. IV, 1967, Katedra - kaplica św. Mikołaja.

21 WojCIECHOWSKi 1900, s. 123-124; KALINOWSKA 1991, s. 140-142.

22 Crossley 1985, s. 31; Walczak 1992; WęCŁAWOWicz 2014, s. 74 i przyp. 79 - autor sugerował, że galeria była częścią pierwotnej aranżacji kaplicy, ponieważ ceremonia okazywania tego relikwiarza [głowy św. Stanisława - P.P.] jest wzmiankowana w źródłach już w roku 1328. Jednak z dokumentu Jana Grota z tego roku wynika tylko tyle, że relikwiarz okazywano gdzieś w katedrze, a gotycki korpus kościoła jeszcze wówczas nie istniał. Galeria musiałaby więc powstać jeszcze w obrębie katedry romańskiej, ku czemu nie ma jednak jakichkolwiek przesłanek, tym bardziej że skomunikowana była ze schodami w wieży powstałej na początku XV wieku. Najstarszym źródłem wprost mówiącym o prezentacji relikwii głowy św. Stanisława z galerii nad kaplicą jest natomiast Liber beneficiorum Długosza (DŁugosz, [LB], t. 1, s. 257). Zdaniem Węcławowicza (WĘCŁAWOWICZ 2014, s. 74 i przyp. 81) podobna galeria mogła też istnieć przy kaplicy św. św. Piotra i Pawła, jednak teza ta nie jest poparta żadnymi reliktami architektonicznymi ani źródłami.
} 
do arkady, jako że jej południowo-wschodni narożnik został wycięty w taki sposób, by ująć zachodnią podporę otworu. Przy tej okazji wnętrze arkady zostało chyba jednak przelicowane - wszystkie widoczne dziś spod tynku partie ościeży i podniebienia arkady wykonane są z dużych ciosów wapienia, podobnie jak ściany wieży ${ }^{23}$. Arkada była nadto na tyle niska, że ponad nią można było w niewysokiej nawie bocznej przeprowadzić wspomnianą galeryjkę, co mogło wynikać z faktu, że po podniesieniu poziomu posadzki w nowym korpusie znaczna jej część znalazła się pod ziemią. Wreszcie asymetryczne usytuowanie arkady blisko zachodniego krańca kaplicy może być przesłanką potwierdzającą tezę o przedłużeniu w wieku XIV pierwotnej, mniejszej budowli.

Na marginesie powyższych uwag o formie i datowaniu kaplic warto odnieść się do zarysowanej w dotychczasowych badaniach opozycji między ich wcieleniami „romańskimi”, to jest trzynastowiecznymi, a „gotyckimi”, czyli z wieku XIV. Z kolei Janusz Firlet uznał, że pierwotna kaplica św. św. Piotra i Pawła nie była budowlą „romańską”, lecz „wczesnogotycką”, nie mając jednak na myśli datowania, ale kwestię kamiennego wątku z warstwami wyrównawczymi, charakterystycznego w Krakowie dla drugiej połowy wieku XIII oraz całego następnego stulecia ${ }^{24}$. W istocie o wyglądzie obu kaplic przed rokiem 1320 wiemy jednak tak niewiele (a o zastosowanym w nim detalu zgoła nic), że używanie w odniesieniu do nich jakichkolwiek kategorii stylowych wydaje się bezzasadne.

Kaplica św. św. Piotra i Pawła, obok ołtarza w skrzyżowaniu nawy i transeptu, była miejscem najsilniej w całej katedrze związanym z kultem św. Stanisława. $\mathrm{Z}$ połowy XV wieku pochodzą źródła informujące o eksponowaniu w niej relikwii ręki męczennika. O ile Miracula Prandoty informują o tym fakcie tylko ogólnie, to nieco zagadkowo brzmi przekaz Długosza, według którego relikwie prezentowano nie tyle w, co z kaplicy (ex qua $)^{25}$. Wojciechowski połączył tę zaskakującą informację z niewielkim, ostrołukowym otworem mierzącym około 1,5 metra wysokości i 0,5 metra szerokości, którego obramienie zachowało się od strony nawy południowej, pierwotnie najpewniej komunikującym obie przestrzenie (il. 10). Badacz upatrywał w tej strukturze rodzaju otworu hagioskopijnego, w który wstawiano relikwiarz - dostępny w ten sposób prywatnej weneracji wiernych ${ }^{26}$. Alternatywną interpretację otworu przedstawił Tomasz Węcławowicz, którego zdaniem było to wejście na umieszczone wewnątrz kaplicy lub w grubości muru schody prowadzące

\footnotetext{
23 Wobec tego niezrozumiała jest uwaga Wojciechowskiego (WoJCIECHOWsKi 1900, s. 124), powtórzona przez Janinę Kalinowską (KALINOWSKA 1991, s. 149) o wykonaniu arkady z cegły.

24 Firlet 2016, s. 167.

$25 \mathrm{MPH}, 4$, s. 447; DŁUGosz [1887], s. 403.

26 WojCIECHOWSKi 1900, s. 139-142.
} 
na planowaną w południowym ramieniu transeptu emporę ${ }^{27}$. Według relacji Wojciechowskiego Sławomir Odrzywolski usunął jednak zamurowanie otworu do około połowy grubości muru, to jest do głębokości 82 centymetrów, natrafiając jedynie na ciągnące się dalej w głąb gładkie ościeża ${ }^{28}$. Z drugiej strony otwory hagioskopijne w ścisłym sensie tego terminu (którego jednak Wojciechowski nie zastosował), choć w późnym średniowieczu wciąż spotykane, przybierały zazwyczaj formę niewielkich szczelinek lub okienek ${ }^{29}$. Omawiany otwór został wypruty w murze o dużej grubości i sięgał aż do posadzki, toteż miał charakter ciasnego tunelu. Być może $\mathrm{w}$ istocie, tak jak wyobrażał sobie Wojciechowski, wstawiano doń relikwiarz zabezpieczony kratą, mógł jednak stanowić też rodzaj pokutnego wejścia dla pielgrzymów, wymuszającego wkraczanie do kaplicy na kolanach. Warto też odnotować ogólne podobieństwo krakowskiego otworu do tzw. the Holy Hole - dwunastowiecznego tunelu usytuowanego pod platformą, na której wyniesiono ołtarz katedry w Winchesterze, umożliwiającego wiernym przedostanie się jak najbliżej relikwii miejscowych świętych ${ }^{30}$ (il. 11). Nie można więc wykluczyć funkcjonowania na Wawelu swego rodzaju drogi pielgrzymkowej, w której wierni wchodzili do kaplicy owym tunelem, zaś wychodzili większą arkadą prowadzącą ku relikwiom.

Według opisu kaplicy w Liber benficiorum Długosza znajdował się w niej jeszcze jeden obiekt związany ze św. Stanisławem - był to kamienny sarkofag, w którym niegdyś znajdowały się szczątki biskupa ${ }^{31}$. Historiograf nie określił, w jakim okresie sarkofag ów był używany; w Rocznikach zapisał jednak, że ciało świętego w roku 1088, po przeniesieniu ze Skałki, spoczęło w pobliżu południowego wejścia do katedry, co nie stoi w sprzeczności z usytuowaniem kaplicy przy południowej nawie katedry ${ }^{32}$. Nie ma jednak żadnych przesłanek, by sądzić, że kaplica powstała wcześniej niż w latach 40. XIII wieku, sama katedra zaś w roku 1088 dopiero powstawała albo też zachowywała jeszcze pierwotną postać $\mathrm{z}$ początku XI wieku ${ }^{33}$.

\footnotetext{
27 WĘCŁAWOWICZ 2004, s. 89-90; WĘCŁAWOWiCZ 2014, s. 74 i przyp. 81 - wobec wyników sondażu archeologicznego w kaplicy autor skłania się ku schodom w grubości muru; zob. też: RoŻNOWSKA-SADRAEI 2008, s. 243-244; por. FirLeT 2016, s. 169.

28 WOJCIECHOWSKI 1900, s. 140.

29 Zob. Le Pogam 2003, s. 171-178; Kratzke 2005, s. 71-97.

30 CROOK 2011, s. 176-178.

31 DŁugosz [LB], 1, s. 233-234: Altare [...] habens capellam propriam versus meridiem positiam, in qua optimi Cracoviensis pontificis Prandothae corpus requiescit, et sanctissimi quondam Cracoviensis praesulis Stanislai ossa ex Rumpella translata in sarcophago saxeo, quod etiam in diem hodiernum cernitur, quiescebant [wytłuszczenie - P.P.].

32 DŁugosz [1887], s. 149; DŁugosz [1974], s. 119.

33 Chronologia budowy katedry romańskiej nie jest dobrze uchwytna, a jedyne poświadczone źródłowo daty to pochówek biskupa Maura w krypcie zachodniej w roku 1118 oraz konsekracja, która nastąpiła dopiero w roku 1142. Największym optymistą w kwestii tempa jej budowy był Pietrusiński, którego zdaniem prace rozpoczęły się około roku 1070 z fundacji Bolesława Szczodrego,
} 
TECHN E

T E X N H

SERIA NOWA

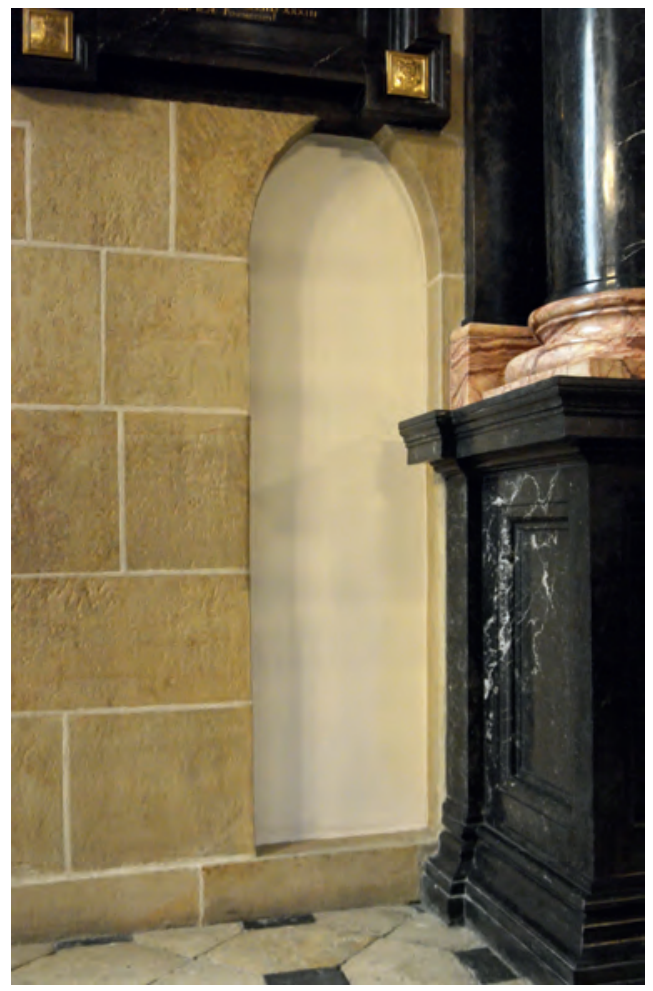

10. Kraków, katedra, otwór w ścianie nawy południowej pierwotnie prowadzący do kaplicy św. św. Piotra i Pawła, fot. autor

Od drugiej połowy XIX stulecia nieomal jako naukowy dogmat funkcjonuje przekonanie, że główna partykuła relikwii św. Stanisława spoczęła na ołtarzu, pośrodku nawy katedry podczas obchodów kanonizacji biskupa w roku $1254^{34}$. Maria Starnawska jako pierwsza podjęła próbę podważenia tego przekonania, sugerując, że relikwie złożono pośrodku kościoła dopiero podczas konsekracji w roku $1364^{35}$. W istocie, jakkolwiek nie ma tu miejsca na szczegółową analizę, żadne średniowieczne źródła nie podają informacji o umieszczeniu relikwii in medio

a dziewięć lat później, w momencie jego detronizacji, były już dalece zaawansowane. Do roku 1088 budowa miała wręcz zostać w zasadniczym zrębie zakończona, o czym świadczyć ma m.in. właśnie przeniesienie do katedry szczątków św. Stanisława (PIETRUSIŃSKI 1996, s. 88-90). Według Klementyny Żurowskiej budowa katedry romańskiej rozpoczęła się dopiero około roku 1090, a dwa lata wcześniej szczątki biskupa przeniesiono do jeszcze istniejącego najstarszego kościoła (ŻurowsKa 1972, s. 68). Zbigniew Pianowski uznał, że budowa rozpoczęła się na długo przed rokiem 1100, a przed 1142 doszło do zmiany warsztatu i koncepcji (PIANOWSKI 2006, s. 181).

34 Zob. m.in.: Polkowski 1885, s. 12-15; WojCIECHOWSKi 1900, s. 86-87; BorAwsKA 1950, s. 68-69; BEŁCH 1977, s. 19; RoŻEK 1979, s. 439; CROSSley 1985, s. 48.

35 STARNAWSKA 2008, s. 207-213. 


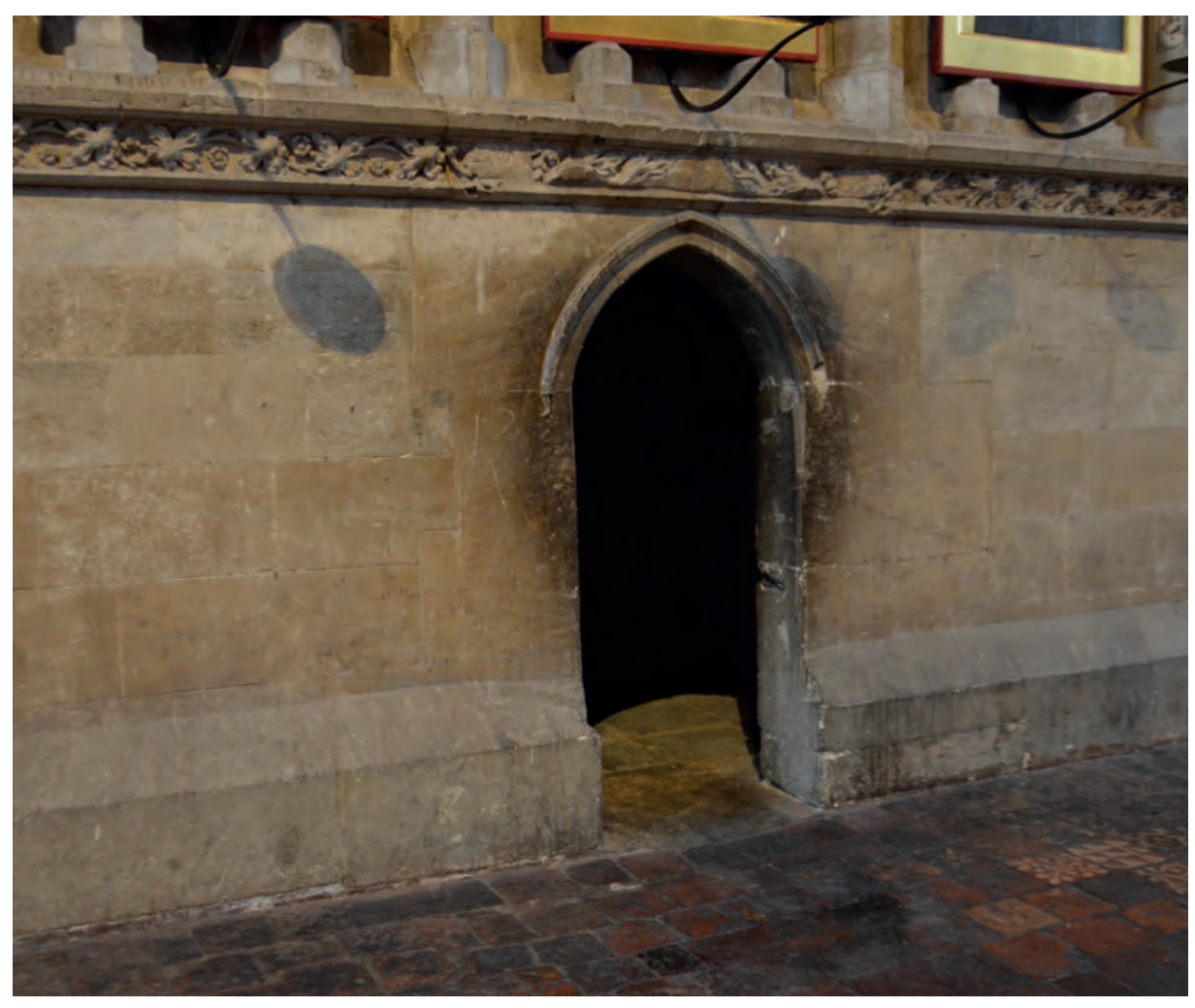

11. Winchester, katedra, tzw. the Holy Hole, fot. autor

ecclesiae przez Prandotę, a jedynie o ich elewacji i obmyciu ${ }^{36}$. Ogłoszona dwa lata później bulla Aleksandra IV wzmiankuje translację świętych szczątków z miejsca na miejsce, ale także bez określenia, dokąd dokładnie ${ }^{37}$. Wydaje się więc prawdopodobne, że w latach 50. XIII wieku Prandota dokonał translacji relikwii św. Stanisława, uprzednio podniesionych z grobu wziemnego, i przeniósł je do ufundowanej przez siebie kaplicy, być może specjalnie w tym celu zbudowanej. Najbardziej prawdopodobnym momentem translacji relikwii na środek kościoła, wbrew zdaniu Starnawskiej, wydaje się jednak konsekracja prezbiterium katedry w roku 1346. Wspomniany dokument Bodzanty, dotyczący kaplicy św. św. Piotra i Pawła, określający jej lokalizację jako iuxta thumbam, zdaje się bowiem wskazywać, że relikwii już wówczas w niej nie było. Na uwagę zasługuje też fakt, że dopiero w roku 1349 uposażono

$36 \mathrm{MPH}, 4$, s. 710; MPH, s.n. 8, s. 101; DŁugosz [1974], s. 119; DŁugosz [1887], s. 149, 176-177 i 241. O złożeniu ciała św. Stanisława pośrodku kościoła informuje jedynie spisany kilka lat po kanonizacji Żywot większy Wincentego z Kielczy, ale określa tak pozycję grobu z roku 1088 (MPH, 4, s. 394).

37 KDKK, 1, nr 51. 
w tak ważnej kaplicy altarię św. św. Piotra i Pawła, chociaż o funkcjonowaniu altarii św. Mikołaja wiemy już z okresu wcześniejszego. Moim zdaniem można ten fakt uznać za poszlakę wskazującą, że wcześniej w kaplicy mieścił się ołtarz św. Stanisława, przeniesiony do przęsła krzyżowego w około 1346 roku. Nie był to jedyny ołtarz w katedrze, który w okresie czternastowiecznej przebudowy zmienił położenie. Na przykład u schyłku dziejów katedry romańskiej, w roku 1302 kanonik Racław uposażył altarię Narodzenia NMP z ołtarzem o nieznanej lokalizacjii ${ }^{38}$. W drugiej połowie XIV wieku obiekt ten znalazł się w nowo wybudowanej kaplicy osiowej. Bodzanta zaznaczył nadto, że fundacji dokonał na prośbę kantora Piotra, który złożył datek na budowę katedry; może nie jest więc przypadkiem, że ołtarz poświęcony był m.in. jego patronowi.

Warto dodać, że praktyka fundowania ołtarza patronowi donatora lub jego krewnego była w katedrze spotykana: Kazimierz Wielki przy grobie Władysława Łokietka ufundował ołtarz św. Władysława ${ }^{39}$, z kolei budowę ołtarza św. św. Jakuba i Klemensa sfinansował w roku 1407 Klemens z Moskorzewa ${ }^{40}$. Wątpliwości budzi jednak kwestia sarkofagu, zapewne sprawionego przez Prandotę, a w XV wieku przechowywanego w kaplicy. Wspomniany opis kaplicy iuxta thumbam nie sugeruje jego obecności w tym wnętrzu; nie ulega zresztą wątpliwości, że na czas radykalnej przebudowy obiektu musiał on zostać chociaż czasowo przeniesiony. Z drugiej strony Krzysztof Czyżewski udowodnił, że srebrny relikwiarz skrzyniowy, znany z nowożytnych opisów i przetopiony po Potopie szwedzkim, ufundowała dopiero Elżbieta Łokietkówna, zapewne w latach 70. XIV wieku ${ }^{41}$. Nie wiadomo więc, jak przechowywano relikwie między rokiem około 1346 a momentem powstania nowego relikwiarza. W związku z tym prawdopodobne wydaje się, że elementem nowego ołtarza św. Stanisława pośrodku katedry był (początkowo przeniesiony z kaplicy) sarkofag fundacji Prandoty. Po zastąpieniu starego relikwiarza nowym ten pierwszy wrócił na dawne miejsce, gdzie oglądał go Jan Długosz.

Jeszcze bardziej enigmatycznie rysuje się kwestia początków i form obyczaju prezentowania relikwii głowy św. Stanisława w kaplicy św. Mikołaja. Najstarszym pewnym potwierdzeniem funkcjonowania zwyczaju prezentacji relikwii z platformy otwierającej się z wnętrza kaplicy św. Mikołaja ku nawie północnej jest opis kaplicy Hińczy z Rogowa w Liber beneficiorum Długosza, sytuujący ją pod miejscem, $z$ którego okazuje się głowęśw. Stanisława ${ }^{42}$. Podobna informacja znalazła się jeszcze na początku XVII wieku w wizytacji Bernarda Maciejowskiego ${ }^{43}$. Z drugiej

\footnotetext{
38 KDKK, t. 1, nr 106.

39 DŁugosz [LB], 1, s. 220; zob. Kumor 1998, s. 347; WalCZaK 2006, s. 82.

40 Kumor 1998, s. 325-326.

41 CZYŻEWSKi 2003, s. 12-29.

42 DŁugosz, [LB], 1, s. 257; (...) sub loco, in quo caput S. Stanislai (...) ostendi solitum est.

43 WOJCIECHOWSKI 1900, s. 125.
} 
strony według relacji Martina Grunewega pod koniec XVI wieku przynajmniej w niektóre święta relikwiarz kryjący czaszkę św. Stanisława prezentowano także z okienka w kracie otaczającej ołtarz pośrodku katedry; wiadomo też, że relikwię tę na stałe przechowywano wówczas w skarbcu katedralnym ${ }^{44}$. Nie jest jednak jasne, w jakim okresie należy upatrywać początków takiej funkcji kaplicy św. Mikołaja. Często odnoszono do niej dokumenty Jana Grota z lat 1328 i 1336, rozporządzające m.in. datkami składanymi przy głowie świętego, jednak bez określenia miejsca weneracji relikwiarza ${ }^{45}$. Zazwyczaj zakładano dużą stałość miejsc czczenia poszczególnych relikwii, jednak topografia kultu św. Stanisława, jak już widzieliśmy, przeszła w XIV wieku gruntowne przemiany. Za równie prawdopodobne trzeba więc uznać trzy możliwości: że kaplica św. Mikołaja była miejscem eksponowania relikwii głowy biskupa już w XIII wieku, że funkcję tę nadano jej około połowy XIV wieku, gdy dawna budowla została przekształcona i włączona w obręb nowej katedry, a wreszcie - że zwyczaj zapoczątkował dopiero Oleśnicki, wznosząc galerię w nawie południowej. Ponadto kaplica nie była jedynym miejscem, w którym wierni mogli oglądać relikwiarz głowy.

Podsumowując powyższe rozważania, należy stwierdzić, że obie omawiane kaplice powstały najpewniej w XIII wieku. Kaplicę południową wzniesiono około połowy tego stulecia $\mathrm{z}$ fundacji biskupa Prandoty, prawdopodobnie w związku z kanonizacją św. Stanisława, którego relikwie znajdowały się w niej do około roku 1346. Była to więc typowa kaplica relikwiarzowa, jakich w średniowiecznej Europie powstało bardzo wiele. Brak przesłanek do bardziej precyzyjnego datowania kaplicy północnej. Oba obiekty powiększono i przekształcono krótko przed połową XIV stulecia; kaplicy południowej prawdopodobnie wówczas nadano nowe wezwanie. Obie zostały skomunikowane z transeptem, w którym ostatecznie ulokowano ołtarz św. Stanisława, jednak w samych kaplicach także eksponowano relikwie krakowskiego męczennika.

Ostatecznie więc kult współpatrona katedry i Królestwa Polskiego został zorganizowany w trzech miejscach ułożonych w jednej linii - poprzecznie względem głównej osi kościoła. Układ ten stanowi jedną z najoryginalniejszych aranżacji kultu relikwii w późnośredniowiecznej Europie. Rozwiązaniem unikalnym jest już samo umieszczenie ołtarza męczennika pośrodku transeptu, stanowiące może odwołanie do wzorów wczesnochrześcijańskich. Stworzenie w kościele osi liturgiczno-ideowej poświęconej jednemu świętemu przywodzi jednak na myśl przede wszystkim katedrę w Canterbury, w której po przebudowie z przełomu XII i XIII wieku czczono w osobnych, umieszczonych osiowo kaplicach ciało oraz czubek głowy św. Tomasza Becketta (do którego żywota zadziwiająco podobne były losy św. Stanisława i którego w katedrze krakowskiej czczono w osobnej kaplicy), a w krypcie poniżej znajdował

44 GruneweG, s. 818; źródła dot. przechowywania relikwii zestawił: CZYŻEWsKi 2008, s. 245-246.

45 KDKK, 1, nr. 145 i 158. 
się także pusty, lecz zachowany pierwotny grób ${ }^{46}$. Krzyżowa kompozycja najważniejszych miejsc kultu w katedrze krakowskiej do pewnego stopnia zdaje się też jednak antycypować podobne rozmieszczenie relikwii św. św. Wacława, Wojciecha, Zygmunta i Wita w katedrze w Pradze ${ }^{47}$.

\section{Bibliografia}

\section{Źródła}

AZK - Archiwum Zamku Królewskiego na Wawelu.

DŁugosz, [LB] - Ioannis Dlugossi, Liber Beneficiorum Dioecesis Cracoviensis, t. 1-3, wyd. Aleksander Przezdziecki, Cracoviae 1863-1864 (=Joannis Dlugossii Senioris Canonici Cracoviensis, Opera omnia, t. 8).

DŁugosz [1887] - Joannis Dlugossi, Opera. Vita S. Stanislai - Vita B. Kunegundis - Vitae episcoporum poloniae - Vita Sbignei de Oleśnica cardinalis - Clenodia. Banderia Prutenorum - Epistolae, wyd. Ignatius Polkowski, Żegota Pauli, Cracoviae 1887 (=Joannis Dlugossii Senioris Canonici Cracoviensis, Opera omnia, t. 1).

DŁugosz [1974] - Jana Długosza Roczniki czyli kroniki sławnego Królestwa Polskiego, księga siódma, księga ósma, Warszawa 1974.

GRUNEWEG - Die Aufzeichnungen des Dominikaners Martin Gruneweg (1562-ca. 1618): über seine Familie in Danzig, seine Handelsreisen in Osteuropa und sein Klosterleben in Polen, wyd. Almut Bues, Wiesbaden 2008.

KDKK - Kodeks dyplomatyczny katedry krakowskiej ś. Wacława, t. 1-2, wyd. Franciszek Piekosiński, Kraków 1874-1883.

MPH - Monumenta Poloniae Historica. Pomniki dziejowe Polski, t. 1-4, Lwów 1864-1884.

MPV - Monumenta Poloniae Vaticana, t. 1, Cracoviae 1913.

\section{Opracowania}

Albrecht 2003 - Stephan Albrecht, Die Inszenierung der Vergangenheit im Mittelalter. Die Klöster von Glastonbury und Saint-Denis, München 2003.

BEŁCH 1977 - Stanisław Bełch, Święty Stanisław. Biskup Męczennik. Patron Polaków, London 1977.

BINSKi 2004 - Paul Binski, Becket's Crown. Art and Imagination in Gothic England, New HavenLondon 2004.

BorAwsKa 1950 - Danuta Borawska, Z dziejów jednej legendy. W sprawie genezy kultu św. Stanisława biskupa, Warszawa 1950.

BRACHMANN 2008 - Christoph Brachmann, Um 1300. Vorparlerische Architektur im Elsass, in Lothringen und Südwestdeutschland, Korb 2008.

46 Szeroką analizę funkcjonowania katedry w Canterbury jako sanktuarium św. Tomasza zob.

w: WALCZAK 2001, s. 88-117; zob. też BINSKI 2004, s. 3-28.

47 Crossley 2001, s. 51-53; UličnÝ 2015, s. 191-195. 
Crook 2011 - John Crook, English Medieval Shrines, Woodbridge 2011.

Crossley 1985 - Paul Crossley, Gothic Architecture in the Reign of Kasimir the Great. Church Architecture in Lesser Poland 1320-1380, Kraków 1985.

Crossley 2001 - Paul Crossley, Bohemia Sacra and Polonia Sacra. Liturgy and History in Prague and Krakow Cathedrals, „Folia Historiae Artium”, Nova Series, t. 7 (2001), s. 49-69.

CzyżEwski 2003 - Krzysztof J. Czyżewski, Srebrne wyposażenie średniowiecznego ołtarza św. Stanisława w Katedrze Krakowskiej, „Folia Historica Cracoviensia”, t. 9 (2003), s. 11-52.

CzYŻEwski 2008 - Krzysztof J. Czyżewski, Martin Gruneweg o krakowskiej katedrze, [w:] „Żeby wiedzieć". Studia dedykowane Helenie Małkiewiczównie, red. Wojciech Walanus, Kraków 2008, s. 243-256.

CzYżEwski 2016 - Krzysztof J. Czyżewski, Kaplica Wazów - czyli ostatnie mauzoleum jagiellońskie na Wawelu, „Studia Waweliana”, t. 17 (2016), s. 77-129.

FIRLET 2016 - Janusz Firlet, Badania archeologiczno-architektoniczne we wnętrzu kaplicy Wazów przy katedrze krakowskiej, „Studia Waweliana”, t. 17 (2016), s. 163-170.

Firlet/PiAnOwSKi 2000 - Janusz Firlet, Zbigniew Pianowski, Przemiany architektury rezydencji monarszej oraz katedry na Wawelu w świetle nowych badań, „Kwartalnik architektury i Urbanistyki”, t. 44 (2000), z. 4, s. 207-236.

Firlet/PiAnOwsKi 2017 - Janusz Firlet, Zbigniew Pianowski, Zespół katedry krakowskiej w XI i XII wieku, [w:] Klejnot w koronie. 650-lecie konsekracji katedry krakowskiej, red. Jacek Urban, Ewelina Zych, Kraków 2017, s. 45-62.

HoRN 2017 - Hauke Horn, Erinnerungen, geschrieben in Stein. Spuren der Vergangenheit in der mittelalterlichen Kirchenarchitektur, Berlin 2017.

JANICKI 2003 - Marek Janicki, Zaginione inskrypcje poetyckie katedry wawelskiej (do końca XVI wieku), cz. 1: Epitafia biskupie i królewskie, „Studia Waweliana”, t. 11-12 (2002-2003), s. 43-72.

KALINOWSKA 1991 - Janina Kalinowska, Kaplica Jana Hinczy w katedrze na Wawelu i jej malowidła ścienne, „Studia do Dziejów Wawelu”, t. 5 (1991), s. 133-231.

KratzKe 2005 - Christine Kratzke, Ausstrahlung und Anblick. Hagioskope in mittelalterlichen Klosterkirchen der Zisterzienser und Zisterzienserinnen im architekturhistorischen Kontext, [w:] Licht und Farbe in der mittelalterlichen Backsteinarchitekur des südlichen Ostseeraums, red. Ernst Badstübner et al., Berlin 2005, s. 71-97.

Kumor 1998 - Bolesław S. Kumor, Dzieje diecezji krakowskiej do roku 1795, t. 1, Kraków 1998.

Le Pogam 2003 - Pierre-Yves Le Pogam, The Hagioscope in the Princely Chapels in France from the $13^{\text {th }}$ to the $15^{\text {th }}$ Century, [w:] Court chapels of the High and Late Middle Ages and their Artistic Decoration: Proceedings from the International Symposium, red. Jiř́ Fajt, Praha 2003, s. 171-178.

PIANOwski 2006 - Zbigniew Pianowski, Architektura monumentalna wczesnośredniowiecznego Krakowa, [w:] Kraków w chrześcijańskiej Europie X-XIII wieku, red. Elżbieta Firlet, Emil Zaitz, Kraków 2006, s. 163-220.

PIANOWski 2007 - Zbigniew Pianowski, Wawel około roku 1250, „Wiadomości Konserwatorskie”, t. 21 (2007), s. 11-14.

Pietrusiński 1975 - Jerzy Pietrusiński, Katedra krakowska - biskupia czy królewska. Dzieje fundacji, [w:] Sztuka i ideologia XIV wieku. Materiały Sympozjum Komitetu Nauk o Sztuce Polskiej Akademii Nauk, Warszawa, 29 i 30 listopada 1973, red. Piotr Skubiszewski, Warszawa 1975, s. 249-273.

PietrusińsKi 1996 - Jerzy Pietrusiński, Krakowska katedra romańska fundacji króla Bolesława II Szczodrego, [w:] Katedra krakowska w średniowieczu. Materiały Sesji Oddziału Krakowskiego Stowarzyszenia Historyków Sztuki, Kraków 1996, s. 43-107.

POLKOWSKi 1885 - Ignacy Polkowski, Grób i trumna ś. Stanisława na Wawelu. Studium archeologiczno-historyczne, Kraków 1885. 
Rożek 1979 - Michał Rożek, Ara Patriae. Dzieje grobu św. Stanisława w katedrze na Wawelu, „Analecta Cracoviensia”, t. 11 (1979), s. 433-460.

RożEK 1980 - Michał Rożek, Katedra wawelska w XVII w., Kraków 1980.

RoŻNOwSKa-SAdraei 2008 - Agnieszka Rożnowska-Sadraei, Pater Patriae. The Cult of Saint Stanislaus and the Patronage of Polish Kings 1200-1455, Kraków 2008.

STARNAWSKA 2008 - Maria Starnawska, Świętych życie po życiu. Relikwie w kulturze religijnej na ziemiach polskich $w$ średniowieczu, Warszawa 2008.

UliČnÝ 2015 - Petr Uličný, The Choirs of St Vitus's Cathedral in Prague: A Marriage of Liturgy, Coronation, Royal Necropolis and Piety, „Journal of the British Archaeological Association”, t. 168 (2015), s. 186-233.

WALCZAK 1992 - Marek Walczak, Przemiany architektoniczne katedry krakowskiej w pierwszej połowie XV wieku i ich związek $z$ działalnościa fundacyjna kardynała Zbigniewa Oleśnickiego, „Studia Waweliana”, t. 1 (1992), s. 7-28.

WALCZAK 2001 - Marek Walczak, „Alter Christus”. Studia nad obrazowaniem świętości w sztuce średniowiecznej na przykładzie św. Tomasza Becketa, Kraków 2001.

WALCZAK 2006 - Marek Walczak, Rzeźba architektoniczna w Małopolsce za czasów Kazimierza Wielkiego, Kraków 2006.

WĘCŁAWOWICZ 2005 - Tomasz Węcławowicz, Krakowski kościół katedralny w wiekach średnich. Funkcje i możliwości interpretacji, Kraków 2005.

WęCŁAWOWICZ 2014 - Tomasz Węcławowicz, Królewski kościół katedralny na Wawelu. W rocznicę konsekracji 1364-2014, Kraków 2014.

WojCIECHOWsKi 1900 - Tadeusz Wojciechowski, Kościót katedralny w Krakowie, Kraków 1900.

ŻurowsKa 1972 - Klementyna Żurowska, Geneza zachodniej części tak zwanej drugiej katedry wawelskiej, „Zeszyty Naukowe UJ. Prace z Historii Sztuki”, t. 10 (1972), s. 35-72. 


\section{Chapels of St. st. Peter and Paul and St. Nicholasin the space of the Cracow cathedral in the $13^{\text {th }}-15^{\text {th }}$ centuries}

$\mathrm{T}$

he article presents a proposal for a new reading of the functions, history and formal transformations of the chapels of St. st. Peter and Paul and St. Nicholas. The chapels were added to the aisles of the romanesque cathedral, but during the construction of the present church (1320-1364) they were included in the new building, which lead to their extensive reconstruction and enlargement. The time and circumstances of the construction of the chapel of St. Nicholas are unknown. Chapel of St. st. Peter and Paul, according to the local tradition, in its original form, was founded by Bishop Prandota, most likely in connection with the cult of St. Stanislaus, canonized in 1253. Although, according to almost all the literature to date, a year later the saint's relics were placed in the center of the nave of the cathedral, it seems more likely that they were placed in the aforementioned chapel. In the Gothic cathedral, the altar of St. Stanislaus was moved to its central point, but the chapel of St. st. Peter and Paul retained an important role in the worship of the martyr, as it included his arm reliquary, and from some point on also an old empty sarcophagus, in which, after canonization, the main particle of the remains were laid. In the $15^{\text {th }}$ century chapel of St. Nicholas was the place where the reliquary of the saint's head was presented. Fot this purpose, gallery was erected above its entrance. The chapels were extended so that they joined both the aisles and the transept, in the center of which the altar of St. Stanislaus was placed; thus, all three objects form a line that crosses the main axis of the church. It seems that the decision for such a sacral topography composition was made already during the construction of the cathedral, modifying the original project, assuming the erection of a narrow transept.

Keywords: cult of Saints, relics, Gothic architecture, Kraków, Middle Ages 